\title{
An Exploration of Integrating History of the Communist Party of China into Translation Teaching for English Majors
}

\author{
Huijun Fu, Ling Sun \\ Baoding University, Baoding, China \\ Email: 496472980@qq.com
}

How to cite this paper: Fu, H. J., \& Sun, L. (2021). An Exploration of Integrating History of the Communist Party of China into Translation Teaching for English Majors. Creative Education, 12, 1153-1159. https://doi.org/10.4236/ce.2021.125085

Received: April 16, 2021

Accepted: May 25, 2021

Published: May 28, 2021

Copyright $\odot 2021$ by author(s) and Scientific Research Publishing Inc. This work is licensed under the Creative Commons Attribution International License (CC BY 4.0).

http://creativecommons.org/licenses/by/4.0/

\begin{abstract}
The history of the Communist Party of China (CPC) reflects the glorious traditions and fine conduct of the $\mathrm{CPC}$, as well as the great Chinese ethos. The study mainly focuses on integrating CPC history into translation teaching for English majors through analyzing the necessity of the study and the current problems appeared in the integrating process. Then some strategies are put forward from translation talent training scheme, translation teacher's competences, teaching contents, and so on. The study is expected to promote the cultivation of a new type of translation talents who are competent, professional and possess both integrity and ability.
\end{abstract}

\section{Keywords}

CPC History, Translation Teaching, Integrating Strategies

\section{Introduction}

The History of the Communist Party of China (CPC) is the precious treasure for the Chinese nation. Since its founding in Jul. 1921, the CPC has experienced nearly 100 years of glorious history. During the 100 years, the CPC has united and led the people in completing the New Democratic Revolution and founding the People's Republic of China in 1949; completing socialist revolution, establishing socialism as China's basic system and advancing socialist construction; launching the reform and opening-up and embarking on the path of socialism with Chinese characteristics; and working harder toward the goal of national rejuvenation.

Translation is the core course for English majors. With the development of social economy, the demand for translators is increasing sharply. Qualified 
translation teaching can ensure the output quality of translation talents. President Xi Jinping stressed at the National Conference on Ideological and Political Work of Colleges and Universities that ideological and political work should be carried out in the whole process of education and teaching to realize the whole-process and all-round education, and all kinds of courses should be developed in the same direction with ideological and political theory courses to achieve the effect of synergy (Xi, 2016). Therefore, translation teaching should not only aim at imparting translation knowledge and cultivating translation competencies, but also aim at realizing the education of political and virtuous awareness of students, so as to cultivate students' confidence in the path, theory, system and culture of socialism and boost their patriotism. CPC history provides precious moral teaching materials for the translation course. To integrate the $\mathrm{CPC}$ history into translation teaching for English majors has great significance.

\section{The Necessity of the Study on Integrating CPC History into Translation Teaching}

On Feb. 20, 2021, the CPC launched a campaign on Party history learning and education among all of its members. President Xi (2021) called for efforts to study the Party's history, understand its theories, do practical work and make new advances, so as to fully build a modern socialist China and welcome the Party's centenary with outstanding achievements. Xi stressed the vital necessity of launching the campaign as the CPC stands at a critical juncture where the timeframes of its two centenary goals converge. He called on all CPC members to carry forward the traditions from revolutionary times, maintain the brave spirit of the revolutionaries, and march toward a brand new journey. He also promoted the learning and education among youngsters to pass on the traditions of revolution through generations. Therefore, the study on integrating CPC history into translation teaching is quite necessary. The main reasons are mentioned as follows:

CPC history is a quality resource of ideology and politics for translation teaching. Through always adhering to the original aspiration of seeking happiness for the Chinese people and the mission of seeking rejuvenation for the Chinese nation, the CPC has led Chinese people to overcome all kinds of barriers and difficulties, and achieved the tremendous transformation from standing up and growing rich to becoming strong, thus embracing the brilliant prospects of rejuvenation. History is the best textbook. CPC history reflects the brave revolutionary spirit, the precious convictions, political stands, value pursuit and ideological style of communists. This provides inexhaustible supply for the ideological and political resources of translation teaching.

CPC history can realize the function of talent cultivation in translation teaching. The course of struggle and great achievements of the CPC can contribute to students' systematic cognition to the Communist Party of China, develop their sense of patriotism, inspire their enthusiasm of building the motherland, and 
further foster their capability of shouldering the mission of national rejuvenation. The glorious traditions, exemplary working styles and strong convictions can refine students' characters, enlighten their wisdom, and develop their social responsibilities and innovation. Integrating CPC history into translation teaching can lead students to square their personal interests with those of the country, and cultivate the correct value orientation, so as to achieve the goal of fostering and practicing core socialist values, as well as cultivating students' virtues and morality. Translation teaching is to realize the cultivation of translation talents for the Party and the country, lead them telling well the Chinese story, and contribute to the opening up of the Chinese culture. Therefore, the history of the CPC should be introduced in translation teaching.

Through searching on CNKI (China National Knowledge Infrastructure), at present there are 18 domestic papers on integrating political and virtuous awareness into translation teaching. It is obvious that moral education has aroused attention of more and more foreign language teachers and scholars in China. As the education of CPC history is only a part of the moral education, the researchers made a further investigation on the integration of CPC history with English teaching, and found that there is only one domestic paper and no related paper abroad. Chai \& $\mathrm{Li}$ (2020) made a research on the integration of the history of CPC and PRC (People's Republic of China) with college English teaching. They focused on the status quo of college English class integrated with the moral education, and discussed ways of integration of CPC history and PRC history with college English teaching by taking the example of New Century College English (Book 2). The discussion of integration is mainly about ways of class organization, which provides references for related studies. However, there is no study on integrating CPC history into translation teaching for English majors at home and abroad. As the campaign of learning CPC history has been formally carried out nationwide since Feb. 2021, the study in this respect is a new perspective and is also quite urgent.

\section{Current Problems of Integrating CPC History into Translation Teaching}

At present, integrating CPC history into translation teaching of English majors is not going well. There are many problems existing in the integrating process, which seriously affect the development of the moral education in translation teaching. In order to investigate the existing problems, the research group designed the questionnaire. Altogether 240 copies of questionnaire were distributed to respondents majoring in English. All the respondents are from Grade 3. They come from three universities in Baoding, which are Baoding University, Hebei University, Hebei Agricultural University. Finally, 232 copies of questionnaire were valid. At the same time, an interview was carried out among 18 translation teachers. The result of the investigation reveals the current problems.

First, some translation teachers have not realized the importance of carrying out the education of CPC history in the translation class. Some teachers espe- 
cially the young teachers don't have a clear grasp of CPC history. They lack the study of CPC history in their daily life, and have a shallow understanding of the CPC history. Many translation teachers are accustomed to teaching translation theories and methods or assigning regular translation exercises to students. Due to the inexperience in teaching ideology and politics, many translation teachers lack the initiative and innovation of integrating the $\mathrm{CPC}$ history into translation teaching.

Second, the whole process of translation teaching is based on translation textbooks. The teaching contents have not been updated. The textbook itself lack ideological and political elements with Chinese characteristics. The western cultural elements take up for the majority of textbook contents, thus the western values are highlighted excessively. The teaching procedure of each unit is almost the same. The teaching aims for the translation course are not comprehensive, as the moral education has not been given enough consideration. The teaching methods are quite overt and not flexible. It is difficult for many translation teachers to make full use of the CPC history resources to subtly influence students' ideology in the translation teaching process. Some teachers just purely let students do translations about the CPC history without leading them to understand the spiritual connotations of CPC history, so the teaching effect is not satisfactory. Besides, the evaluation of translation teaching has certain defects, such as lacking the evaluation of students' ideology and the evaluation of overall professional competencies.

Third, many students only focus on learning the contents of translation textbook. They only understand translation methods, but lack the correspondent training of translation skills. Their autonomous learning ability has not been fully developed. Some students don't have good command of both English and Chinese languages, which causes many language mistakes in translation. Students don't have enough storage of cultural knowledge. The translation of English to Chinese makes up a great proportion of translation practice, while Chinese to English translation practice has not been given due attention. Some students tend to lack the interest of translating Chinese classics, such as the history of the CPC. Born after 2000s, students also don't have deep understanding of the CPC history and they are in lack of cultural confidence. Their learning of CPC history in the translation class is quite passive. Besides, translation is not only the bridge of two languages, but also the communication of two different cultures. As to the ideological aspect, qualified translation talents should have deeper love for the country. However, students haven't received adequate education about professional ethics, ideals, beliefs, and national consciousness in the translation class.

\section{The Strategies of Integrating CPC History into Translation Teaching for English Majors}

The problems discussed in the above chapter needs to be solved urgently. As an important component of ideological and political contents, CPC history should 
be integrated into translation teaching for English majors. As this is a new teaching reform, the following strategies are discussed and put into practice.

1) Translation talent training scheme

The university should set up more scientific training scheme for cultivating interdisciplinary translation talents. The teaching objectives should highlight the cultivation of translation talents with excellent morals and academic skills. The affective education and patriotic education should also be incorporated in the teaching objectives and specific teaching design, so as to cultivate translation talents to love the motherland, tell well Chinese stories and spread Chinese culture. CPC history is full of great revolutionary spirits of the older generation of proletarian revolutionist. It is beneficial for the younger generation to develop the correct belief deep in their hearts, scientific conception of history, and the great ambition of serving the country and the people. CPC history plays an irreplaceable role in moral education. Therefore, learning the history of the CPC should be included in the translation talent training scheme to foster character and civic virtue, lead students develop the right worldview, outlook on life, and values, and realize all-round education of translation talents.

2) Translation teachers' competences

The integration of the CPC history into translation teaching for English majors places higher demands for the competences of translation teachers. Promoting translation teachers' competences can guarantee the high quality of translation teaching. First of all, translation teachers should make it clear that the cultivation for translation talents is for the Party and the country. Translation talents are the main force of socialist construction. Leading students to study the CPC history can cultivate their strong belief in the CPC and resolutions of rejuvenating the great country. Second, translation teachers should promote their competence of political theories. They need to further study the history of the CPC and ensure the learning quality. Only if translation teachers grasp solid knowledge of CPC history can they perfectly integrate it into the translation teaching. Third, translation teachers are required to have a good command of translation theories and rich experience in translation practice. Integrating CPC history into translation teaching is a challenging task for translation teachers. In the translation process of CPC history, both teachers and students will face challenges from the selection of words to the organization of sentences, paragraphs and passages. Translation teachers should give students effective guidance based on their professional translation competences.

3) Teaching contents

Translation teaching for English majors mainly involves two parts, i.e., the teaching of translation theories and the teaching of translation practice. Metaphysical translation theories should be avoided in the teaching of translation theories. Teachers should introduce some practical western translation theories such as Communicative Translation Theory, Functional Equivalence Theory, Text Typology Theory, Interpretation Theory, etc. Translation teachers should also introduce the theories of famous Chinese translators such as Fu Yan, Xun 
$\mathrm{Lu}$, Lei Fu, Zhongshu Qian, etc. The teaching of translation practice includes the cultivation of translation skills, the explanation of translation process and specific translation practice. As to the translation practice, teachers should study the contents of CPC history and explore proper integrating points with the translation teaching, thus developing a synergistic system of the CPC history and the translation course. Based on teaching needs, the contents of CPC history should be selected from various angles varying from stories, characters, spirits to different styles. CPC history provides limitless resources for translation classes, so it should be better utilized as the high-quality teaching content.

4) Teaching methods

In order to better integrate CPC history into translation teaching for English majors, teachers should adopt diversified teaching methods. First, translation teachers should carry out student-centered teaching. Students are encouraged to have group discussions and cooperate to translate the materials of CPC history according to different teaching themes. Translation teachers can adopt heuristic teaching method, give students specific guidance and advice on translation tasks, and enlighten them to obtain practical translation strategies and skills. By this way, teachers can promote the combination of knowledge instruction and value guidance in translation teaching. Second, translation teachers can carry out blended teaching through integrating online and offline learning resources. Translation teachers should build digital repository of the translation teaching of CPC history, and promote students' inquiry learning and autonomous learning. Third, abundant extracurricular activities should be carried out actively. The university can organize translation contests and translation workshops, both of which should involve the knowledge of CPC history. Translation teachers can organize students to visit local memorial halls or interview the local Red Army veterans, then encourage them to translate the red culture into English. Besides, students can also appreciate and translate different styles of CPC history such as poems, prose, novels, songs, etc. By this way, teachers not only arouse students' interest in the translation practice of CPC history, but strengthen the education of ideology, ethics and socialist core values.

5) Teaching evaluations

According to The Overall Plan for Deepening the Reform of Education Evaluation in the New Era (2020), universities should reform the evaluation of students to promote the all-round development of morality, intelligence, physique, beauty and labor. Therefore, the evaluations of the translation teaching for English majors should be diverse. The teaching evaluations should not merely focus on the scores of mid-term exam or final exam. Translation teachers should attach great importance to the evaluations of students' learning process, which involve evaluations of students' patriotism, moral character, translation knowledge, translation practical ability, application of translation software, innovation ability, etc. Teaching evaluations can adopt various ways, such as translation teacher's evaluation, peer evaluation, and even students' self-evaluation. No matter what criteria and ways the evaluations adopt, CPC history should be in- 
tegrated into the teaching evaluations. The translation of CPC history as well as the ideological and spiritual understanding of the CPC history should be incorporated into the range of evaluations, so as to develop into a scientific and comprehensive teaching evaluation system.

\section{Conclusion}

President Xi (2019) once emphasized that "historical research is the foundation of all social sciences". He attaches special importance to the history of the Communist Party of China. Nowadays, integrating the CPC history into translation teaching for English majors is of practical importance. Translation teaching aims to realize the cultivation of students' deeper love for the country, proficient translation skills, and international horizons. Translation talents should be educated to stick to the correct political stance and tell well of Chinese stories in the future translation careers. Integrating CPC history into translation teaching has the function of ideological and political education, which will influence students' sentiment, purify their mind, cultivate their patriotism, and educate them to inherit the red genes and dedicate to the country and the people. At present, the research has made certain achievements, and the research results have been applied to the translation teaching practice. However, how to optimize the digital repository of the translation teaching of CPC history still deserves to be explored further. It is also expected that the integrating strategies will be applied to more universities in the near future.

\section{Conflicts of Interest}

The authors declare no conflicts of interest regarding the publication of this paper.

\section{References}

Chai, T., \& Li, G. D. (2020). Exploring the Ways of Integrating CPC and PRC History into College English Teaching: Taking the Example of New Century College English (Book 2). China Journal of Multimedia \& Network Teaching, 3, 211-212.

The Overall Plan for Deepening the Reform of Education Evaluation in the New Era (2020). The Central Committee of the Communist Party of China (CPC) and the State Council.

http://www.moe.gov.cn/jyb_xxgk/moe_1777/moe_1778/202010/t20201013_494381.ht $\underline{\mathrm{ml}}$

Xi, J. P. (2016). Speech at the National Conference on Ideological and Political Work of Colleges and Universities. http://www.xinhuanet.com/politics/2016-12/08/c_1120082577.htm

Xi, J. P. (2019). Xi Jinping's Congratulatory Letter to the Establishment of the Chinese Academy of History of the Chinese Academy of Social Sciences. Historical Research, 1, 4.

Xi, J. P. (2021). Speech on Party History Educational Campaign.

http://www.qstheory.cn/dukan/qs/2021-03/31/c_1127274518.htm 